\title{
Effects of the blended learning model on preservice teachers' academic achievements and twenty-first century skills
}

\section{Cihad Şentürk ${ }^{1}$ (D)}

Received: 15 May 2020 / Accepted: 16 September 2020 / Published online: 1 October 2020

(C) Springer Science+Business Media, LLC, part of Springer Nature 2020

\begin{abstract}
The purpose of this study was to examine the effects of a blended teaching-learning approach on academic achievement and twenty-first century skills of preservice teachers who took the teaching principles and methods course. The implementation was carried out over a period of ten weeks with preservice teachers who were enrolled in pedagogical training at the Faculty of Education at Karamanoğlu Mehmetbey University in the 2019-2020 academic year. In the study, a semi-experimental research design with experimental and control groups was employed. Data collection tools were an academic achievement test and "multidimensional twenty-first century skills scale". Analysis revealed that there was a significant difference across the two groups' academic achievement and twenty-first century skills in favor of the experimental group. In addition, analysis of the retention test administered four weeks later showed a significant difference in favor of the experimental group. In the light of the results, the implications and future directions were discussed.
\end{abstract}

Keywords Blended learning model-Preservice teacher education - Academic achievement - Retention test - Twenty-first century skills

\section{Introduction}

Rapid changes and developments in science and technology in the world have affected countries, societies and economies, as well as the schools and education systems established in order to shape the future of countries (Council of Europe 2015; United Nations 2019). Especially the changes occurring in recent years can be accounted for by the developments in the information and communication technologies (ICT).

Cihad Șentürk

cihadsenturk@gmail.com

1 Faculty of Education, Karamanoğlu Mehmetbey University, Karaman, Turkey 
Furthermore, the developments in ICT have had direct consequences on the way education is organized (Allen and Velden 2013). As a result of these changes and developments in the world, the need has emerged to reconsider the purpose and content of education, teachers, education programs and the education process, as well as the role of the school as a learning organization, and it has become important to educate individuals equipped with the skills required by the twenty-first Century (Council of Europe 2015; OECD 2018). All these developments have also influenced the learningteaching theories, and new theories, models and approaches or new paradigms have been introduced according to the requirements of the age (Reigeluth 2012; Scott 2015). One of these new approaches is the blended learning model that blends face-to-face instruction with online instruction. Since technology has become an essential part of our daily lives, benefiting from digital learning technologies inside and outside the classroom in the learning-teaching process has become imperative. In addition, it should be noted that research has reported that the blending learning model has made significant and positive effects on educational outcomes.

In broad terms, blended learning is defined as the integration of face-to-face instruction with computer-mediated instruction (Bonk and Graham 2006). In the literature, different terms including "hybrid learning" and "mixed-mode" learning have been used. Whereas these two concepts are used interchangeably, the use of the term "hybrid learning" is more common, especially in the United States (Martyn 2003). However, in other countries like Turkey, it is less common to use the term "hybrid" as it means that two different species come together to create a new species. In addition to this, since "blended" means establishing a proper harmony and balance to achieve the best, it is not accepted as a completely new type of learning environment (Osguthorpe and Graham 2003; Singh 2003). The goal of teaching in the blended learning environment is to provide an eclectic approach that aims to minimize the weaknesses of different learning methods and maximize their strengths to provide the most effective learning environment (Brown 2016; Graham 2006; Williams et al. 2008). Therefore, the term "blended learning" was preferred in this study.

The blended learning model is a way to integrate face-to-face classroom teaching with online virtual classroom environments (Doering 2006). In other words, blended learning involves integrating activities in different environments including face-to-face teaching and e-learning with its own steps (Garrison and Vaughan 2008). Blended learning is generally defined as the combination of the strengths and advantages of inclass face-to-face learning activities and web-based online learning to achieve the most appropriate benefits (Bersin 2004; Garrison and Kanuka 2004; Stain and Graham 2014). As a pedagogical approach, it combines face-to-face instruction with computer-mediated education (Ferdig et al. 2012). In the blended learning model, face-to-face classroom learning and internet-based online learning are integrated in educationally meaningful ways (Stain and Graham 2014). Driscoll (2002) states that blended learning is carried out by combining four elements. These elements are (1) combining different web-based technologies (live virtual classes, individual learning, cooperative learning, video, voice and text) to achieve educational goals, (2) gathering together different pedagogical approaches (structuralist, behavioral, cognitive) by using educational technologies to achieve the best learning outcome, (3) mixing a teachercentered face-to-face learning environment with any educational technology (videotape, CD-ROM, web-based learning, movie, etc.) and (4) integrating educational 
technology and real-life tasks to create a harmonious effect. Based on all these definitions, the blended learning model and its learning design elements are presented in Fig. 1.

As seen in Fig. 1, the blended learning model consists of two dimensions: in-class as the face-to-face instruction and out-of-class as the virtual education dimensions. In the face-to-face instruction, teaching is carried out in the classroom environment and reinforced and deepened in the virtual learning dimension by digital learning tools (Ross and Gage 2006). Blended learning offers learners flexible learning opportunities. Besides face-to-face education, it enables students to learn anytime and anywhere without space and time limitation (Stein and Graham 2014). Blended learning increases student-teacher and student-student interaction, and provides a more dynamic and interactive learning environment, which leads to a higher level of participation (Donnelly 2009). Moreover, it provides learners with additional learning opportunities and helps them to achieve deeper and more meaningful learning levels and to solve complex problems (Patrick and Sturgis 2015). In addition, learners in the blended learning model can demonstrate their ability to reflect themselves socially and academically in the virtual learning environment as well as in face-to-face education. In today's world, as lifelong learning becomes very important, the acquisition of digital learning skills becomes imperative in order to be lifelong learners. In addition, the blended learning model helps learners improve their skills to use various information technologies, and enables individuals to make progress towards becoming technologically literate (Cleveland-Innes and Wilton 2018). In this respect, it can be stated that it will be beneficial to use the blended learning model in teaching and learning to accomplish the educational output and comprehensive learning experience.

In the twenty-first century, the expectations that an individual should have are constantly changing (Dede 2010). These expectations are generally expressed as the twenty-first century skills. Some of these skills are learning and renewal skills (self-

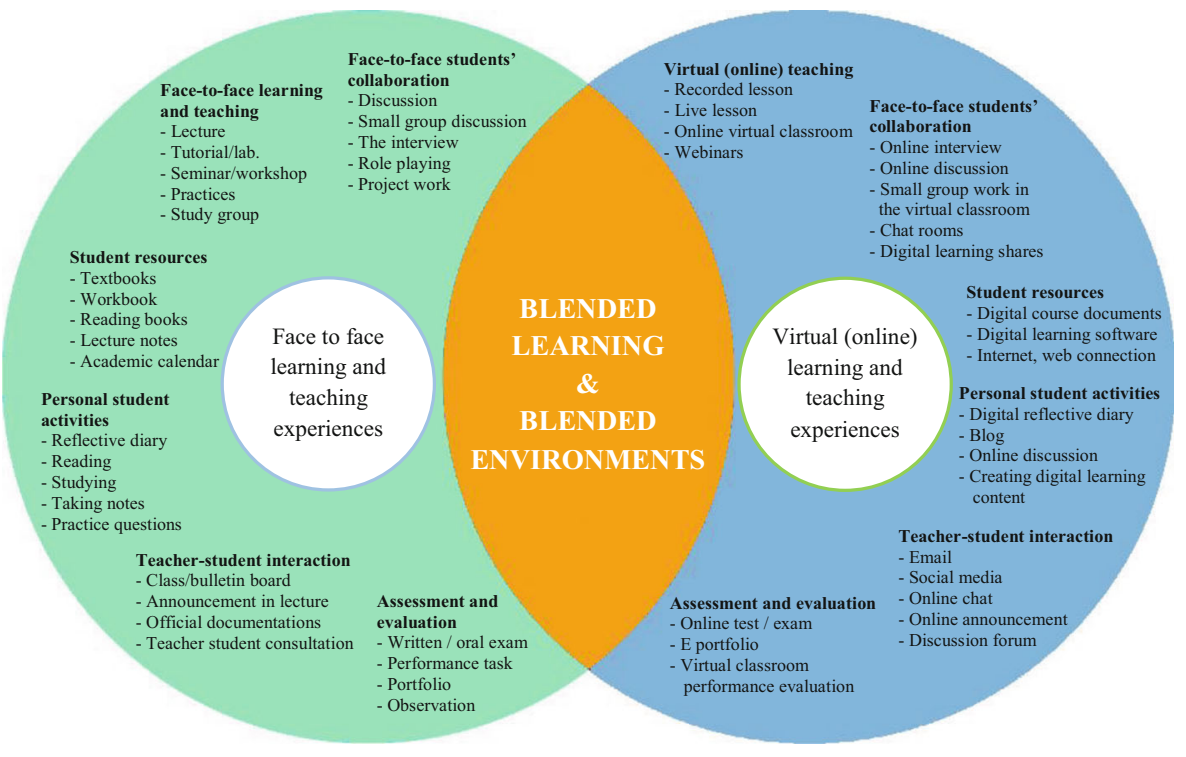

Fig. 1 Blended learning model and its elements (adapted from Bath and Bourke 2010) 
directed learning, critical thinking, problem solving, communication and cooperation), information, media and technology skills (information literacy, media literacy, science and mathematics literacy), information and communication technologies (ICT) literacy, daily life and professional skills (flexibility and harmony, entrepreneurship and selfdirection, social and intercultural skills, productivity, leadership and responsibility) (Binkley et al. 2010; Partnership for twenty-first Century Skills 2009). It has been argued that it is impossible to foster individuals' twenty-first century skills with the traditional education approach. In this respect, it is very important that education systems, schools and education programs should be designed in a way that provides students with rich opportunities to acquire these skills. In this regard, it is vital that the implementation of modern learning and teaching approaches meets the expectations of the century and fosters the skills and equipment required by the age. The aim of this study is that the blending learning model, one of the contemporary learning approaches that blends face-to-face education and distance education and contributes to twenty-first century skills such as learning to learn, self-directed learning, deepening learning, reflective and critical thinking, problem solving, information and technology literacy, will have a positive influence on students' academic achievement, their twenty-first century skills and their lifelong learning (Atef and Medhat 2015; Huang et al. 2008).

\subsection{Study purposes}

This study aimed to examine the effects of the blended learning model on preservice teachers' academic achievement and twenty-first century skills in the teaching principles and methods course. With this purpose, answers to the following research questions were sought:

1 What is the effect of blended learning experiences on preservice teachers' academic success and long-term learning?

2 What is the effect of blended learning experiences on preservice teachers' twentyfirst century skills?

\section{Methodology}

In this part of the study, the research model of the study, the procedure, the data collection tools and analysis of the data are presented.

\subsection{Research model}

In the study, a quasi-experimental research design with pretest-posttest was used. The quasi-experimental designs are used to examine the cause-effect relationships between variables. Based on the comparison of pre-tests and post-tests in quasi-experimental studies, the effect of the model employed in the research on the experimental group can be investigated (Büyüköztürk 2016). The design used in the study is displayed in Table 1.

In the study, there were two groups, one as the experiment group and the other as the control group. The pre-test was administered to both groups before the implementation, 
Table 1 Design of the quasi-experimental study

\begin{tabular}{llll}
\hline Groups & Pre-test & Experimental Process & Post-test \\
\hline Experimental Group & $\mathrm{T}_{1}$ and $\mathrm{T}_{2}$ & Blended Learning-Teaching Implementation & $\mathrm{T}_{1}$ and $\mathrm{T}_{2}$ \\
Control Group & $\mathrm{T}_{1}$ and $\mathrm{T}_{2}$ & Traditional Method in the Current Curriculum & $\mathrm{T}_{1}$ and $\mathrm{T}_{2}$ \\
\hline
\end{tabular}

$\mathrm{T}_{1}$ : Academic achievement test, $\mathrm{T}_{2}$ : Multidimensional twenty-first Century skills scale.

and based on the results of the pre-test, participants were randomly assigned to either the experimental or the control group by ensuring that there was no statistically significant difference in achievement and twenty-first century skills between groups ( $p>.05$; Creswell 2014; Fraenkel et al. 2012). While the blended learning model instruction was implemented in the experimental group, the control group was exposed to the regular teaching instruction. In the pre-test, the "Academic Achievement Test" developed by the researcher and the "Multidimensional $21^{\text {st }}$ Century Skills Scale" developed by Çevik and Şentürk (2019) were applied to preservice teachers in both groups. At the end of the experimental implementation, the same data collection tools were administered as post-tests.

\subsection{Participants}

The participants were preservice teachers who were enrolled in the pedagogical training certificate program at the Faculty of Education in Karamanoğlu Mehmetbey University in the fall semester of the 2019-2020 academic year. Both groups had the same number of participants $(n=86)$, and thus, a total of 172 preservice teachers participated in the study. The participants were recruited to either the experimental or the control group by ensuring that their scores in the pre-test were not statistically significantly different. The results of independent t-tests indicated that there were no statistically significant differences in the academic achievement test $\left(t_{(170)}=-.869, p>0.05\right)$ and the multidimensional twenty-first century skills scale $\left(t_{(170)}=-.489, p>0.05\right)$.

\subsection{The implementation process}

Permission for carrying out the study was granted by the faculty before the implementation. In the study, the blended learning model was implemented in the experimental group for a total of ten weeks between 19.10.2019 and 22.12.2019. At the end of these ten weeks, the post-test was administered to test whether there was a significant difference between the academic achievement and twenty-first century skills of the experimental and control group students. In addition, four weeks after the implementation ended, the "academic achievement test" was re-applied as a retention test and the effect of the blended learning model on retention in learning was examined. The implementation process of the experimental study is briefly described in Fig. 2.

The experimental implementation was carried out by blending synchronous and asynchronous distance education in a virtual classroom created with a software service outside the faculty and face-to-face education in person in the classroom. Teaching methods and techniques including discussion, case study, and problem solving were 


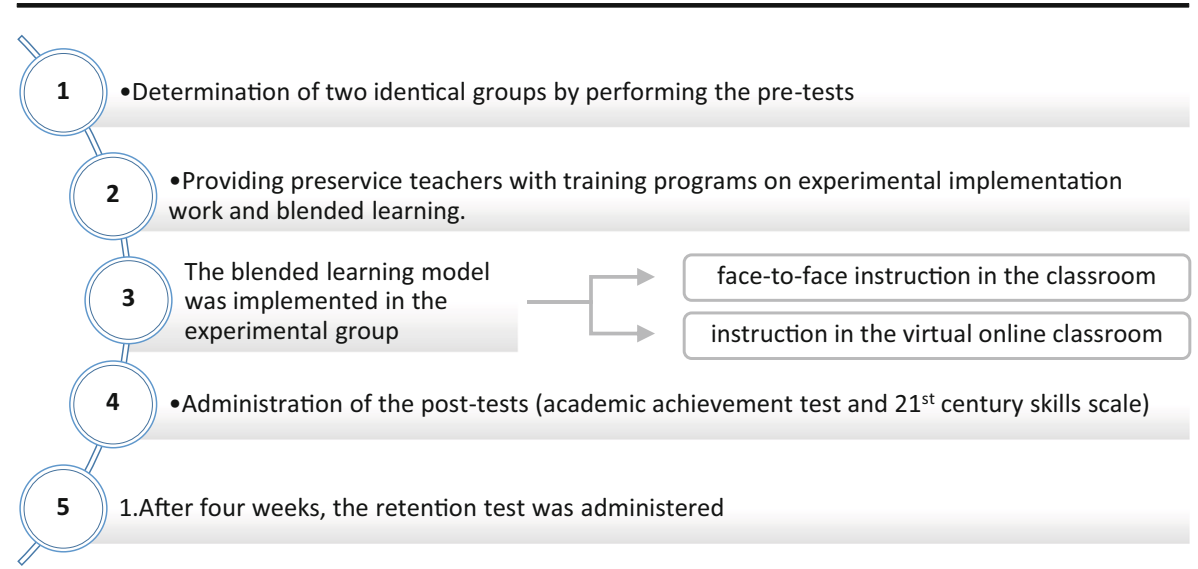

Fig. 2 The experimental implementation process

used. In the virtual classroom dimension, both the instructor and the students shared materials including videos, animations and documents on the topics taught. Comments, discussions and evaluations were made in the virtual classroom environment. In addition, digital learning applications were utilized in the virtual classroom environment via Web 2.0 tools both in the learning-teaching process and in the assessment and evaluation process. By doing this, the preservice teachers were guided to develop digital learning materials and share these materials in the classroom. Moreover, online chats and discussions were carried out from time to time using various software. Sometimes, the instructor guided these discussions, and at other times, the preservice teachers did so. In the online chat or discussion activities, topics that had not been addressed or well understood in the face-to-face education were reviewed. Furthermore, by means of the virtual classroom, the preservice teachers realized that they could control their own learning speeds without time and space limitations, improve their self-study and self-directed learning, and use educational technologies effectively and efficiently. As in the virtual classroom, any topic that was not well understood in the virtual classroom and that preservice teachers would like to go over again was taught in the face-to-face education. In addition, all materials prepared by the preservice teachers in the virtual classroom were created as e-portfolios by the virtual classroom software, and the students' performance was determined.

\subsection{Data collection tools}

In this study, quantitative data were obtained with the "Academic Achievement Test" and "Multidimensional $21^{\text {st }}$ Century Skills Scale" adapted within the scope of the Teaching Principles and Methods course of pedagogical training. Descriptive information about the data collection tools is briefly described below.

\subsection{Academic achievement test}

Within the scope of the Teaching Principles and Methods course, the "Academic Achievement Test" covering "general teaching principles", "teaching theories, models 
and approaches", "teaching strategies", "teaching methods" and "teaching techniques" was developed by the researcher. In order to ensure the content validity of the test, firstly, a table of test specifications was created according to the learning outcomes and contents of the specified topics. A draft academic achievement test consisted of sixty items in the multiple choice test format. The draft academic achievement test was first examined by four experts in the field of educational sciences and some revisions were made to the test in line with the feedback from the experts.

The pilot test for the academic achievement test was carried out with preservice teachers who were enrolled in another faculty but had similar characteristics (e.g. geographical location of the faculty, student and academician profile, etc.) to the preservice teachers in the study groups of the research. The initial analysis of the test scores from the pilot study showed that the average item difficulty index was 0.60 , while the average item discrimination index was 0.51 . After eliminating fifteen items that had low or high item difficulty indices, the final version of the test consisting of forty-five items had a $\mathrm{KR}_{20}$ reliability coefficient of .93 . This value is in the acceptable range of item reliability for a test (Cohen and Swerdlik 2018).

\subsection{Multidimensional twenty-first century skills scale}

The Multidimensional twenty-first Century Skills Scale developed by Çevik and Şentürk (2019) was used to determine the twenty-first century skills of the experimental and control groups before and after the study. As a five-point Likert scale, the questionnaire consists of 5 sub-dimensions and 41 items including "Information and Technology Literacy Skills", "Critical Thinking and Problem-Solving Skills", "Entrepreneurship and Innovation Skills", "Social Responsibility and Leadership Skills" and "Career Awareness". Cronbach's alpha reliability coefficient was .86 for the whole scale, and for the sub-dimensions it was $.84, .79, .76, .73$ and .75 , respectively. In addition, analysis of the confirmatory factor analysis results $\left(\chi^{2} / \mathrm{sd}=2014.17 / 774\right.$; $\mathrm{GFI}=.90 ; \mathrm{AGFI}=.85 ; \mathrm{RMSEA}=.05 ; \mathrm{CFI}=.95 ; \mathrm{NFI}=.91$ and $\mathrm{SRMR}=.058)$ indicated that the fit indices were in the acceptable range for the validity of the instrument (Çevik and Şentürk 2019). To sum up, the instrument was a valid and reliable measurement tool to map the twenty-first century skills of preservice teachers.

\subsection{Data analysis}

In the research, before the analysis of the quantitative data were collected, it was checked whether the data met the assumptions including having a normal distribution and homogeneity between groups. Sample size is an important determiner of normal distribution. In the literature, it is recommended to use the Kolmogorov-Smirnov Z test when the group size is more than 50, and the Shapiro-Wilk test when it is lower than 50 (Büyüköztürk et al. 2013). In this study, since sample sizes in both groups ( $n=86$, for both) were more than 50, the Kolmogorov-Smirnov $\mathrm{Z}$ test was used to check whether the data showed normal distribution. The results of the Kolmogorov-Smirnov Z test showed that the significance value was greater than 0.05 , indicating that the data had normal distribution. Thus, the parametric test was used (Büyüköztürk et al. 2013; Creswell 2012). In order to address the quantitative research questions which aimed at comparing two group means, independent groups t-test was used (Creswell 2012; 
Fraenkel et al. 2012). Descriptive statistics including arithmetic means and standard deviations were given to determine the scores obtained from the groups' achievement test and the twenty-first century skills scale.

\section{Findings}

In this part, the findings related to the research questions are presented.

\subsection{Findings related to the first research question}

The first research question was related to whether there was a statistically significant difference between the academic achievement of the experimental group, in which the blended learning model was implemented, and of the control group at the end of the study. The post-test scores in the academic achievement test of the experimental and control groups were compared and the results of the independent groups $t$-test are given in Table 2.

As seen in Table 2, the post-test mean score of the experimental group in the academic achievement test was $43.04( \pm 1.82)$. The post-test mean score of the control group was $34.68( \pm 4.90)$. Comparison of the post-test mean scores of the experimental and control groups in the academic achievement test showed that there was a statistically significant difference between the groups $\left(t_{(170)}=14.801\right.$, $p<0.05)$. The mean values of the groups indicated that this significant difference was in favor of the students in the experimental group. The effect size coefficient, $r$, which is an indicator of practical significance, was computed as 0.750 (Özsoy and Özsoy 2013). An effect size value between .20 and .49 is regarded as a small effect, between .50 and .79 as a medium effect, and .80 and above as a large effect (Cohen 1988). The large effect size coefficient of the significant difference showed that the blended learning experiences had a high-level effect on students' academic achievement. In the study, in order to determine the long-term learning effects of the implementation, the retention test was administered to the experimental and control group students. Independent groups $t$ test results related to the retention tests are given in Table 3 .

As seen in Table 3, the mean score of the experimental group from the retention test was $42.66( \pm 1.75)$, whereas the mean score of the control group was $30.38( \pm 4.78)$. The independent $t$-test resulted in a statistically significant difference between the groups $\left(t_{(170)}=22.365, p<0.05\right)$. The mean scores of both groups showed that the significant difference was in favor of the students in the experimental group. The effect size

Table 2 Comparison of post-test scores of groups' academic achievement

\begin{tabular}{lllllllll}
\hline Groups & $n$ & Test & $\bar{x}$ & $S D$ & $d f$ & $t$ & $p$ & $r$ \\
\hline Experimental Group & 86 & Post-test & 43.04 & 1.82 & 170 & 14.801 & $0.000^{*}$ & 0.750 \\
Control Group & 86 & Post-test & 34.68 & 4.90 & & & & \\
\hline
\end{tabular}

$* p<0.05$ 
Table 3 Comparison of the groups' retention test results

\begin{tabular}{lllllllll}
\hline Groups & $n$ & Test & $\bar{x}$ & $S D$ & $d f$ & $t$ & $p$ & $r$ \\
\hline Experimental Group & 86 & Retention test & 42.66 & 1.75 & 170 & 22.365 & $0.000 *$ & 0.862 \\
Control Group & 86 & Retention test & 30.38 & 4.78 & & & & \\
\hline
\end{tabular}

$* p<0.05$

coefficient, $r$, was computed as 0.862 , indicating that the blended learning experiences had a high level of impact on long-term learning.

\subsection{Findings related to the second research question}

The second research question was related to whether there was a statistically significant difference between the experimental and the control groups' twenty-first century skills at the end of the treatment. Thus, the post-test scores of the experimental and control groups in the multidimensional twenty-first century skills scale were compared. The results of the analysis from the independent groups $t$-test are displayed in Table 4.

As seen in Table 4, there was a significant difference in favor of the experimental group in all sub-dimensions in the post-test of the twenty-first century skills scale. It was found that the post-test mean score of the whole test in the experimental group in the twenty-first century skills scale was $4.66( \pm 0.20)$, whereas it was $3.06( \pm 0.34)$ for

Table 4 Comparison of groups' twenty-first century skills scale means

\begin{tabular}{|c|c|c|c|c|c|c|c|c|c|}
\hline $\begin{array}{l}\text { Twenty-First century } \\
\text { skills scale }\end{array}$ & Groups & $n$ & Test & $\bar{x}$ & $S S$ & $s d$ & $t$ & $p$ & $r$ \\
\hline \multirow{2}{*}{$\begin{array}{l}\text { Information and } \\
\text { Technology } \\
\text { Literacy Skills }\end{array}$} & $\begin{array}{l}\text { Experimental } \\
\text { Group }\end{array}$ & 86 & Post-test & 4.62 & 0.48 & \multirow[t]{2}{*}{170} & \multirow[t]{2}{*}{16.181} & \multirow[t]{2}{*}{$0.000 *$} & \multirow[t]{2}{*}{0.780} \\
\hline & Control Group & 86 & Post-test & 3.05 & 0.75 & & & & \\
\hline \multirow[t]{2}{*}{$\begin{array}{l}\text { Critical Thinking and } \\
\text { Problem-Solving Skills }\end{array}$} & $\begin{array}{l}\text { Experimental } \\
\text { Group }\end{array}$ & 86 & Post-test & 4.69 & 0.46 & \multirow[t]{2}{*}{170} & \multirow[t]{2}{*}{15.321} & \multirow[t]{2}{*}{$0.000 *$} & \multirow[t]{2}{*}{0.762} \\
\hline & Control Group & 86 & Post-test & 3.18 & 0.78 & & & & \\
\hline \multirow[t]{2}{*}{$\begin{array}{l}\text { Entrepreneurship and } \\
\text { Innovation Skills }\end{array}$} & $\begin{array}{l}\text { Experimental } \\
\text { Group }\end{array}$ & 86 & Post-test & 4.68 & 0.46 & \multirow[t]{2}{*}{170} & \multirow[t]{2}{*}{16.699} & \multirow[t]{2}{*}{$0.000 *$} & \multirow[t]{2}{*}{0.785} \\
\hline & Control Group & 86 & Post-test & 3.01 & 0.81 & & & & \\
\hline \multirow[t]{2}{*}{$\begin{array}{l}\text { Social Responsibility } \\
\text { and Leadership Skills }\end{array}$} & $\begin{array}{l}\text { Experimental } \\
\text { Group }\end{array}$ & 86 & Post-test & 4.67 & 0.47 & \multirow[t]{2}{*}{170} & \multirow[t]{2}{*}{16.625} & \multirow[t]{2}{*}{$0.000^{*}$} & \multirow[t]{2}{*}{0.786} \\
\hline & Control Group & 86 & Post-test & 3.09 & 0.74 & & & & \\
\hline \multirow[t]{2}{*}{ Career Awareness } & $\begin{array}{l}\text { Experimental } \\
\text { Group }\end{array}$ & 86 & Post-test & 4.66 & 0.47 & \multirow[t]{2}{*}{170} & \multirow[t]{2}{*}{17.093} & \multirow[t]{2}{*}{$0.000^{*}$} & \multirow[t]{2}{*}{0.794} \\
\hline & Control Group & 86 & Post-test & 3.02 & 0.75 & & & & \\
\hline \multirow[t]{2}{*}{ Total } & $\begin{array}{l}\text { Experimental } \\
\text { Group }\end{array}$ & 86 & Post-test & 4.66 & 0.20 & \multirow[t]{2}{*}{170} & \multirow[t]{2}{*}{36.928} & \multirow[t]{2}{*}{$0.000 *$} & \multirow[t]{2}{*}{0.944} \\
\hline & Control Group & 86 & Post-test & 3.06 & 0.34 & & & & \\
\hline
\end{tabular}

$* p<0.05$ 
the control group. The independent t-test resulted in a statistically significant difference between the groups $\left(t_{(170)}=36.928, p<0.05\right)$ in favor of the experimental group. The effect was calculated as $r=0.944$, indicating that the blended learning experiences had a high level of effect on students' twenty-first century skills.

\section{Discussion and conclusion}

The aim of this study was to determine the effects of the blended learning model implemented in the teaching principles and methods course of pedagogical training on preservice teachers' academic achievement, long-term learning and twenty-first century skills. The results of the study showed that the blended learning model implemented in the experimental group for ten weeks had more positive influences on the preservice teachers' academic achievement and long-term learning compared to the traditional teaching methods implemented in the control group. The effect size indicated that the blended learning model had a high-level effect on students' academic achievement and long-term learning (for academic achievement $r=.75$ and for the retention test $r=.86$ ). There are several studies that have reported parallel results regarding the effect of blended learning on academic achievement. Studies have reported that the post-test scores of the experimental group students who went through the blended learning process were higher than scores of those who went through the face-to-face learning process only (Alsalhi et al. 2019; Balaman and Tüysüz 2011; Ceylan and Elitok Kesici 2017; Obiedat et al. 2014; Pesen and Oral 2016; Sarıtepeci and Çakır 2015). In addition to this, some studies have reported that the blended learning model positively influenced students' motivation and class participation (Bosch et al. 2019; Saritepeci and Y1ldız 2014), and improved learning (Wai and Seng 2015), self-efficacy (Abello 2018), self-regulated and self-directed learning skills (Uz and Uzun 2018) and long-term learning (Bağcı and Yalın 2018). In this study, a significant difference was found in favor of the experimental group in the retention test. In the light of this finding, it can be stated that preservice teachers achieved long-term learning by developing their selfregulated and self-directed learning skills with the blended learning model, and by repeating and reinforcing what they had learned in face-to-face education via virtual classroom activities outside the school.

Another important result of this study is that the blended learning model fostered preservice teachers' twenty-first century skills (information and technology literacy, critical thinking and problem solving, entrepreneurship and innovation, social responsibility and leadership, and career awareness). In line with these findings, it can be stated that the teacher candidates in the experimental group who experienced the blended learning model developed their twenty-first century skills. In the literature, studies have reported that blended learning has the potential to contribute to various skills including twenty-first century skills. Research has reported that the blended learning model positively contributed to students' problem-solving skills (Suprabha and Subramonian 2019), science process skills (Harahap et al. 2019), professional development skills (Yeh et al. 2011), transfer of learning and knowledge transformation skills (Demirer and Sahin 2013; Jou et al. 2016), self-directed learning skills (Akgunduz and Akinoglu 2016), visual literacy skills (Huilcapi-Collantes et al. 2020), language skills (Hossein and Gwo-Jen 2020; Mingyong 2015), collaborative 
learning skills (Liu and Shi 2016), critical thinking skills (Jou et al. 2016), and selfdetermination for learning (Joo et al. 2013). In addition, Yeh et al. (2011) concluded that the blended learning model developed the professional knowledge and personal teaching efficacy of preservice teachers. In consideration of these studies, it can be stated that the blended learning model improves students' twenty-first century skills.

\subsection{Implications}

The blended learning model contributes to individuals becoming lifelong learners who have the ability to learn continuously anytime and anywhere outside the school and in their professional lives by acquiring self-directed learning skills, which are described as the ability to manage their own learning process (Karataş 2017; Parisi et al. 2019). The results of this study suggest that blended learning with face-to-face instruction and online distance instruction should be included in schools. In today's world in which educational technologies are highly developed, the implementation of such models should be seen as requirements of the age. In this regard, it should be noted that the implementation of this model is more likely to provide significant contributions to students' learning with the qualities required by the age and lifelong learning skills by offering blended learning opportunities to teachers and students through distance education software, especially in universities. In addition, the blended learning model has the potential to enable preservice teachers to become lifelong learners by developing their learning and renewal skills, and they will actively benefit from educational technologies and related approaches throughout their professional life.

In addition, the effectiveness of the blended learning model can be increased by employing different learning-teaching approaches including project-based learning, collaborative learning, differentiated teaching, and flipped learning. Especially due to the Covid-19 epidemic crisis, the importance of distance education has been highlighted once again, and face-to-face education and distance education can be implemented in blended learning models in later periods when life returns to normal.

\subsection{Limitations of the study}

Some limitations exist in this study. The research was carried out in Turkey with a total of 172 candidates who were enrolled in the pedagogical training certificate program of a university faculty of education. Therefore, there are limitations on the generalizability of the research results in the national and international arena. Accordingly, it can be suggested that similar studies should be carried out on a larger scale in the national or international arena. The research can be carried out by creating more experimental and control groups with preservice teachers studying at different universities. As this study was an experimental study with quantitative research methods, further research with qualitative or mixed research methods can be carried out to examine the effects of blended learning in more depth. Furthermore, the effects of the blended learning model on different variables including preservice teachers' attitudes, self-directed learning skills, and perceptions of pedagogical competence can be investigated. In addition, further study can be carried out with in-service teachers. Internationally, comparison 
studies can be carried out examining the effects of the blended learning model on inservice and preservice teachers.

\section{References}

Abello, C. A. M. (2018). How professional development in blended learning influences teachers' self-efficacy. Unpublished doctoral dissertation, Grand Canyon University, Phoenix, Arizona.

Akgunduz, D., \& Akinoglu, O. (2016). The effect of blended learning and social media-supported learning on the students' attitude and self-directed learning skills in science education. The Turkish Online Journal of Educational Technology, 15(2), 106-115.

Allen, J., \& Velden, R. V. D. (2013). Skills for the $21^{\text {st }}$ century: Implications for Dutch education. In L. R. Smit (Ed.), Higher education: Recent trends, emerging issues and future outlook (pp. 1-40). New York: Nova Publishers.

Alsalhi, N. R., Eltahir, M. E., \& Al-Qatawneh, S. S. (2019). The effect of blended learning on the achievement of ninth grade students in science and their attitudes towards its use. Heliyon, 5(9), e02424. https://doi.org/ 10.1016/j.heliyon.2019.e02424.

Atef, H., \& Medhat, M. (2015). Blended learning possibilities in enhancing education, training and development in developing countries: A case study in graphic design courses. TEM Journal, 4(4), 358-365.

Bağcı, H., \& Yalın, H. İ. (2018). The effects of 5E learning cycle model in adaptive blended learning environment to students' academic success. Journal of Theoretical Educational Science, 11(3), 562-585.

Balaman, F., \& Tüysüz, C. (2011). Researching the effect of blended learning model on the science and technology course success, attitudes and motivations of $7^{\text {th }}$ class students. The Western Anatolia Journal of Educational Sciences (WAJES), 2(4), 75-90.

Bath, D., \& Bourke, J. (2010). Getting started with blended learning. Queensland: Griffith University, Griffith Institute for Higher Education.

Bersin, J. (2004). The blended learning book: Best practices, proven methodologies and lessons learned. San Francisco: Pfeiffer.

Binkley, M., Erstad, O., Herman, J., Raizen, S., Ripley, M., \& Rumble, M. (2010). Draft white paper 1: Defining $21^{\text {st }}$ century skills. Assessment \& teaching of $21^{\text {st }}$ century skills [ATCS]. Victoria: The University of Melbourne.

Bonk, C. J., \& Graham, R. (Eds.). (2006). The handbook of blended learning: Global perspectives, local designs. San Francisco: Pfeiffer.

Bosch, C., Mentz, E., \& Reitsma, G. M. (2019). Integrating cooperative learning into the combined blended learning design model. International Journal of Mobile and Blended Learning, 11(1), 58-73.

Brown, M. G. (2016). Blended instructional practice: A review of the empirical literature on instructors' adoption and use of online tools in face-to-face teaching. The Internet and Higher Education, 31, 1-10.

Büyüköztürk, Ș. (2016). Deneysel desenler [Experimental designs]. Ankara: Pegem Akademi Publishing.

Büyüköztürk, Ş., Çokluk, Ö., \& Köklü, N. (2013). Sosyal bilimler için istatistik [Statistics for social sciences] (12th ed.). Ankara: Pegem Akademi Publishing.

Çevik, M., \& Șentürk, C. (2019). Multidimensional $21^{\text {st }}$ century skills scale: Validity and reliability study. Cypriot Journal of Educational Science, 14(1), 11-28.

Ceylan, V. K., \& Elitok Kesici, A. (2017). Effect of blended learning to academic achievement. Journal of Human Sciences, 14(1), 308-320.

Cleveland-Innes, M., \& Wilton, D. (2018). Guide to blended learning. Burnaby: Commonwealth of Learning.

Cohen, J. (1988). Statistical power analysis for the behavioral sciences (2nd ed.). Hillsdale: Lawrence Erlbaum Associates.

Cohen, R. J., \& Swerdlik, M. E. (2018). Psychological testing and assessment (9th ed.). New York: McGrawHill Education.

Council of Europe (2015). Education for change, change for education. Teacher manifesto for the $21^{\text {st }}$ century of the conference. The professional image and ethos of teachers, April 2014. Strasbourg: Council of Europe.

Creswell, J. W. (2012). Educational research: Planning, conducting and evaluating quantitative and qualitative research (4th ed.). Boston: Pearson Education, Inc..

Creswell, J. W. (2014). A concise introduction to mixed methods research. Thousand Oaks: Sage.

Dede, C. (2010). Comparing frameworks for $21^{\text {st }}$ century skills. In J. Bellanca \& R. Brandt (Eds.), $21^{\text {st }}$ century skills: Rethinking how students learn (pp. 51-76). Bloomington: Solution Tree Press. 
Demirer, V., \& Sahin, I. (2013). Effect of blended learning environment on transfer of learning: An experimental study. Journal of Computer Assisted Learning, 29(6), 518-529.

Doering, A. (2006). Adventure learning: Transformative hybrid online educaion. Distance Education, 27(2), 197-215. https://doi.org/10.1080/01587910600789571.

Donnelly, R. (2009). Harmonizing technology with interaction in blended problem-based learning. Computers \& Education, 54(2), 350-359.

Driscoll, M. (2002). Blended learning: Let's get beyond the hype. IBM global services, retrieved from, http:// www-07.ibm.com/services/pdf/blended_learning.pdf [date of access: 29.04.2020].

Ferdig, R., Cavanaugh, C., \& Freidhoff, J. (2012). Lessons learned from blended programs: Experiences and recommendations from the field. Vienna: iNACOL Publishing.

Fraenkel, J. R., Wallen, N. E., \& Hyun, H. H. (2012). How to design and evaluate research in education (8th ed.). New York: McGraw-Hill.

Garrison, D. R., \& Kanuka, H. (2004). Blended learning: Uncovering its transformative potential in higher education. Internet and Higher Education, 7(2), 95-105. https://doi.org/10.1016/j.iheduc.2004.02.001.

Garrison, D. R., \& Vaughan, N. D. (2008). Blended learning in higher education: Framework, principles, and guidelines (1st ed.). San Francisco: Jossey-Bass.

Graham, C. R. (2006). Blended learning systems: Definition, current trends, and future directions. In C. J. Bonk \& C. R. Graham (Eds.), Handbook of blended learning: Global perspectives, local designs (pp. 321). San Francisco: Pfeiffer.

Harahap, F., Nasution, N. E. A., \& Manurung, B. (2019). The effect of blended learning on student's learning achievement and science process skills in plant tissue culture course. International Journal of Instruction, 12(1), 521-538.

Hossein M., \& Gwo-Jen, H. (2020). The effect of online vs. blended learning in developing English language skills by nursing student: An experimental study. Interactive Learning Environments (online first). https:// doi.org/10.1080/10494820.2020.1739079.

Huang, R., Ma, D., \& Zhang, H. (2008, August). Towards a design theory of blended learning curriculum. Proceeding, hybrid learning and education, (first international conference, ICHL), Hong Kong, China.

Huilcapi-Collantes, C., Hernández Martín, A., \& Hernández-Ramos, J. P. (2020). The effect of a blended learning course of visual literacy for inservice teachers. Journal of Information Technology Education: Research, 19, 131-166. https://doi.org/10.28945/4533

Joo, Y. J., Lim, K. Y., Han, S. Y., Ham, Y. K., \& Kang, A. (2013, July). The effects of self-determination on learning outcomes in a blended learning. International conference on e-learning (IADIS), Prague.

Jou, M., Lin, Y.-T., \& Wu, D.-W. (2016). Effect of a blended learning environment on student critical thinking and knowledge transformation. Interactive Learning Environments, 24(6), 1131-1147.

Karataş, K. (2017). Predicting teacher candidates' self-directed learning in readiness levels for terms of metacognitive awareness levels. Hacettepe University Journal of Education, 32(2), 451-465.

Liu R., \& Shi C. (2016). Investigating collaborative learning effect in blended learning environment by utilizing moodle and wechat. In S. K. L. Cheung, J. Shang, A. Wang, \& R. Kwan (Eds.), Blended learning: Aligning theory with practices (pp. 3-13). ICBL 2016. Switzerland: Sringer International Publishing.

Martyn, M. (2003). The hybrid online model: Good practice. Educause Quarterly, 26(1), 18-23.

Mingyong, Z. (2015, February). An empirical research into the effect of blended learning on English writing learning in institutions of higher vocational education. $2^{\text {nd }}$ international conference on electronics and communication systems (ICECS), Coimbatore.

Obiedat, R., Eddeen, L. N., Harfoushi, O., Koury, A., Al-Hamarsheh, M., \& AlAssaf, N. (2014). Effect of blended-learning on academic achievement of students in the University of Jordan. International Journal of Emerging Technologies in Learning (iJET), 9(2), 37-44.

OECD [Organisation for Economic Co-operation and Development]. (2018). The future of education and skills: Education 2030. Paris: OECD indicators, OECD publishing.

Osguthorpe, R. T., \& Graham, C. R. (2003). Blended learning environments. Quarterly Review of Distance Education, 4(3), 227-233.

Özsoy, S., \& Özsoy, G. (2013). Effect size reporting in educational research. Elementary Education Online, $12(2), 334-346$.

Parisi, G. I., Kemker, R., Part, J. L., Kanan, C., \& Wermter, S. (2019). Continual lifelong learning with neural networks: A review. Neural Networks, 113, 54-71.

Partnership for $21^{\text {st }}$ Century Skills. (2009). P21 framework definitions. Retrieved from, http://www.p21.org/ storage/documents/P21_Framework_Definitions.pdf [Date of access: 30.03.2020].

Patrick, S., \& Sturgis, C. (2015). Maximizing competency education and blended learning: Insights from experts. Vienna: iNACOL. 
Pesen, A., \& Oral, B. (2016). The effect of blended learning approach on academic success and motivation of teacher candidates. Electronic Journal of Social Sciences, 15(58), 799-821.

Reigeluth, C. M. (2012). Instructional theory and technology for the new paradigm of education. Revista de Educación a Distancia, XI(32), 1-18.

Ross, B., \& Gage, K. (2006). Global perspectives on blended learning: Insight from WebCT and our customers in higher education. In C. J. Bonk \& C. R. Graham (Eds.), Handbook of blended learning: Global perspectives, local designs (pp. 155-168). San Francisco: Pfeiffer.

Sarıtepeci, M., \& Çakır, H. (2015). The effect of blended learning environments on student's academic achievement and student engagement: A study on social studies course. Education and Science, 40(177), 203-216.

Sarıtepeci, M., \& Yıldız, H. (2014). The effect of blended learning environments on students' engagement to course and motivation toward the course. Journal of Ahi Evran University Kırşehir Faculty of Education (KEFAD), 15(1), 211-223.

Scott, C. L. (2015). The futures of learning 1: Why must learning content and methods change in the $21^{\text {st }}$ century? ERF working papers series, 13. Paris: UNESCO Education Research and Foresight.

Singh, H. (2003). Building effective blended learning programs. Educational Technology, 43(6), 51-54.

Stain, J., \& Graham, C. R. (2014). Essentials for blended learning: A standards-based guide. New York: Routledge.

Stein, J., \& Graham, C. R. (2014). Essentials for blended learning a standards base guide (1st ed.). New York: Routledge.

Suprabha, K., \& Subramonian, G. (2019). Effect of blended learning strategy on problem solving skill of higher secondary commerce students. i-manager's Journal on School Educational Technology, 15(2), $37-44$.

United Nations [UN]. (2019). The future is now: Science for achieving sustainable development. Global sustainable development report. New York: United Nations.

Uz, R., \& Uzun, A. (2018). The influence of blended learning environment on self-regulated and self-directed learning skills of learners. European Journal of Educational Research, 7(4), 877-886.

Wai, C. C., \& Seng, E. L. K. (2015). Measuring the effectiveness of blended learning environment: A case study in Malaysia. Education and Information Technologies, 20, 429-443.

Williams, N. A., Bland, W., \& Christie, G. (2008). Improving student achievement and satisfaction by adopting a blended learning approach to inorganic chemistry. Chemistry Education Research and Practice, 9(1), 43-50.

Yeh, Y. C., Huang, L. Y., \& Yeh, Y. L. (2011). Knowledge management in blended learning: Effects on professional development in creativity instruction. Computers \& Education, 56(1), 146-156.

Publisher's note Springer Nature remains neutral with regard to jurisdictional claims in published maps and institutional affiliations. 